\title{
Management of Culinary Tourism Products in Gunung Kidul Districts
}

\author{
Anggi M.J. Saputri ${ }^{1}$, Yulia Arisnani Widyaningsih ${ }^{2}$ \\ ${ }^{I}$ Department of Industrial Technology Universitas Negeri Malang; \\ ${ }^{2}$ Department Master of Tourism Universitas Gadjah Mada \\ *Corresponding author.Email: anggi.saputri.ft@um.ac.id
}

\begin{abstract}
Gunung Kidul is one of the districts in Yogyakarta. In Gunung Kidul there are many tourist potentials, such as nature tourism and culinary tourism. Natural attractions include beaches, caves, mountains, ponds, hills, tourist villages. While culinary tour includes sego abang, a variety of fish dishes, Gathot, thiwul, jingkeng, fried grasshoppers, seaweed chips. Various types of restaurants are developed, so did the various menus, both types of food and drinks are served with a variety of innovative creations. This is done to attempt to eat competitively with other food businesses. Food and drink in Gunung Kidul can be a tourist attraction that can attract tourists. With the many tourists who visit the tourist resorts, indirectly affect the restaurant business which flourished. The purpose of this study was to determine the factors that influence the decision of tourists who consumes local foods in Gunung Kidul. This research was conducted using qualitative and quantitative research methods, research location taken in Pari Gogo Restaurant in Semanu and Stores souvenirs Gathot thiwul Yu Tum in Wonosari. The research methodology includes survey methods, interviews, and observations. The survey method is done by spreading the questionnaire to the tourists who come to the food stalls and souvenir shops. Interviews were conducted with business owners culinary, culinary business managers, suppliers of raw materials, tourists. The results of this study indicate that several factors influence the decision of tourists to consume local foods in Gunung Kidul district includes the sights and tourist attractions located in Gunung Kidul, and food products sold in Gunung Kidul. Management of local food in Gunung Kidul is done by managing human resources, procurement of raw materials, and services. As for the marketing strategy includes product innovation, competitive pricing sell, provide an adequate place, and promotion of the maximum.
\end{abstract}

Keyword: culinary tourism, Gunung Kidul, Yogyakarta

\section{INTRODUCTION}

Yogyakarta is a tourist city with a cultural background the strong one. The strength of Javanese culture, the number of special foods, goods crafts, and tourist attractions are the main attraction for the traveler. Yogyakarta's special food and handicraft items are a souvenir that is sought after by tourists. This thing became an opportunity for small industries to develop their businesses in terms of make a present.

Yogyakarta is also famous for its cuisine. Many tourists come to Yogyakarta just because they want to taste culinary in Yogyakarta. Local food and outdoor food are served in various restaurants to meet the needs of every tourist for food and drinks. But not a few tourists who choose to consume local food as a favorite food.

One area in Yogyakarta is Gunung Kidul Regency. Unlike the four other districts in the fertile and green Special Region of Yogyakarta, Gunung Kidul is a barren limestone hill that is always hit by drought. Located on the southern coast of Java Island, Gunung Kidul is a remnant of the sea in the past. But now Gunung Kidul is no longer synonymous with drought. The once barren and limestone mountains on the southeast side of the Special Region of Yogyakarta gradually turned green. Besides that Gunung Kidul also has many other tourism potentials.

In Gunung Kidul there are charming beaches which include Baron Beach, Krakal, Kukup, Drini, Sundak, Siung, Sadeng, Ngobaran, Ngrenehan and Indrayanti. In addition, there are also artificial forests, such as Wanagama (owned by Gadjah Mada University / UGM). No less exotic are the challenging karts caves, beautiful stalactites/stalagmites and stunning underground rivers. In Gunung Kidul there are also caves scattered in various places. Some of them are connected, such as Pindul Cave, Japanese Cave. There is also a geological tour of Mount Purba Nglanggeran, the Ancient Bengawan Solo River. Tourism Sri Gethuk Waterfall, Bleberan, Nglanggeran 
In addition to the tourist attractions above, in Gunung Kidul there are also many tourist villages, including Bobung, Mojo, Garotan, Nglanggeran, Bejiharjo, Bleberan, Umbulrejo, Wonosadi, Kemadang, Ngestirejo, Jelok, Sidoharjo, Kemuning, Mulo, and Turunan. The facilities in the tourist village are outbound, nature cruising, cave caving, river trending, plowing the fields, enjoying typical food. With this tourism village, local food is better known by tourists, both local and foreign.

In addition to the tourist attractions above, restaurants/restaurants are also a very important aspect in the development of the tourism industry. Various types of restaurants were developed, as well as various menus, both types of food and drinks served with a variety of innovative creations. The potential of this local cuisine can be a way or answer to start or open a tourism development effort in Gunung Kidul Regency through the development and marketing of culinary tourism products in Gunung Kidul Regency. Furthermore, a culinary tourism product development model must be made appropriate and adapted to the potential and strength of Gunung Kidul Regency

\section{RESEARCH METHOD}

This type of research is included in qualitative research and quantitative research. Qualitative research is research that uses a naturalistic approach to search for and find understanding or understanding of phenomena in a particular contextual setting (Moleong, 2007: 3). Qualitative research questions two aspects, namely the research approach used is naturalistic, while the effort and goal are to understand a phenomenon in Denzin and Lincoln (Moleong, 2007: 3) state that qualitative research is research that uses a scientific setting, intending to interpret phenomena that occur. So that qualitative research is carried out in natural conditions and is a discovery. In qualitative research, researchers are the instrument or key. Therefore, researchers must have the provision of theory and broad insights so they can ask questions, analyze, and construct the object under study to be clearer. This research emphasizes food and is tied to values. Qualitative research is used if the problem is not clear, to find hidden food, to understand social interactions, to develop theories, to ascertain the truth of data, and to examine the historical development

While quantitative research according to Sugiyono (2011: 8 ) is research conducted by collecting answers from respondents or questions that are measurements of the variables studied.

\section{RESULTS AND DISCUSSION}

Based on its geographical location, Gunung Kidul Regency is one of 5 districts in the Special Region of
Yogyakarta Province, with an area of $\pm 1,485.36 \mathrm{~km} 2$ or \pm $46.63 \%$ of the total area of DIY, with administrative boundaries as follows: Northside: Klaten Regency and Sukoharjo Regency. To the south: the Indian Ocean. Westside: Bantul Regency and Sleman Regency Eastside: Wonogiri Regency.

Most of the agriculture owned by Gunung Kidul Regency is $\pm 90 \%$ rain-fed dry land which depends on climate cycles, especially rainfall. Irrigated rice fields are relatively narrow and most are rain-fed rice fields. As for mining natural resources in the form of batu kapur, batu apung, kalsit, zeolit, bentonit, tras, kaolin dan pasir kuarsa. Gunung Kidul Regency also has a fairly wide beach length located in the south bordering the Indian Ocean, stretching for about $65 \mathrm{Km}$ from Purwosari sub-district to Girisubo sub-district. The potential of marine products and tourism is very large and open to be developed.

Most of the residents who live in Gunung Kidul Regency, especially in the area of natural attractions of this beach, farming and fishing livelihoods or all of which are obtained from nature that is sold by themselves and trying their own even though only small-scale like trading along the seashore. However, the potential of the surrounding area, especially the coastal tourism area is very large.

Other potentials are the handicraft, food, and processing of agricultural products, all of which are very potential to be developed. For the sector culture, living conditions and cultural and artistic activities in Gunung Kidul Regency, general are still going well, seen from the efforts and activities of the community to maintain and develop culture and arts which exist. There also appears to be an attempt to re-explore the endangered culture and arts, as well as efforts to regenerate young people.

The existence of tourist objects and attractions in Gunung Kidul provides enormous benefits for the community around the tourism object itself and along the existing tourist transportation routes. These benefits are in the form of equitable development of the region and an increase in community income by establishing tourism such as food stalls/restaurants/food stalls. Gunung Kidul Regency has various types of food and drinks that are unique in nature and can even be said to be a popular food and drink that can be found in every place in the Gunung Kidul Regency. Based on the identification of regional delicacies in the Gunung Gunung Regency it can be concluded that the types and types of delicacies found in the Regency of Gunung Gunung are quite diverse from the main dishes (Sego abang, aneka hidangan ikan) and snacks(Thiwul, Gathot, gethuk goreng, cake thiwul, krecek telo, belalang goreng, belalang bacem, manggleng, rengginang telo, peyek jingkeng, rumput laut, peyek undur-undur). 


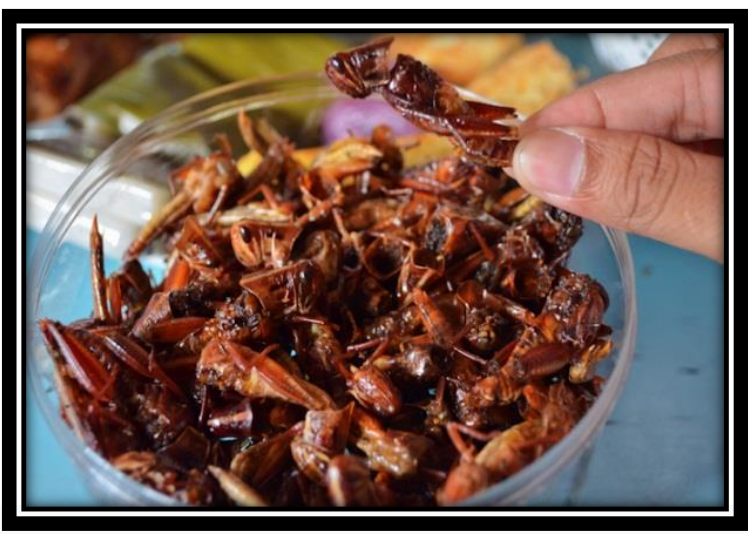

Picture 1 fried grasshopper

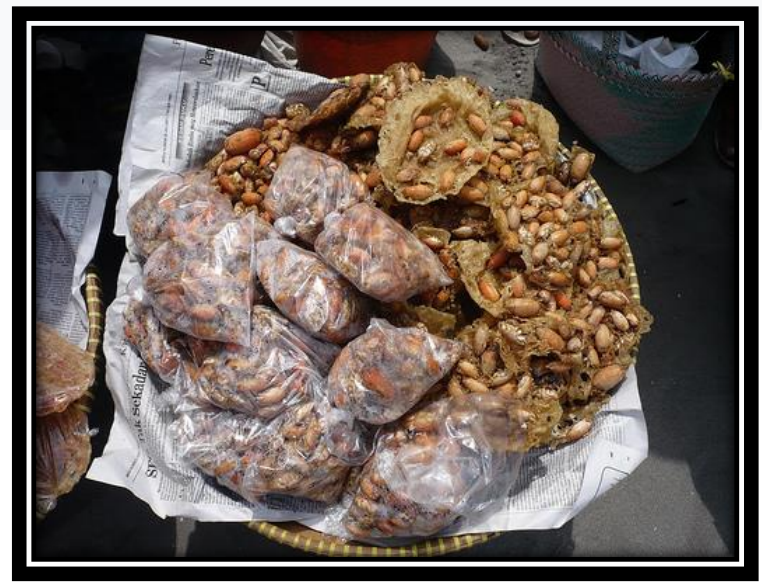

Picture 2 Jingking brittle

The potential of Gunung Kidul Regency in the culinary field is very diverse according to the characteristics of each region. In areas that produce a lot of fish such as Baron beach, Sadeng is often found simple food stalls that sell a variety of processed fish. In the Gunung Kidul region with low rainfall and rocky soil types, only rain-fed rice can flourish. Some of these rainfed rice types offer red rice with a unique taste, namely in the Semanu area. In Semanu, there is a food stall that serves as a special sego abang Gunung Kidul.

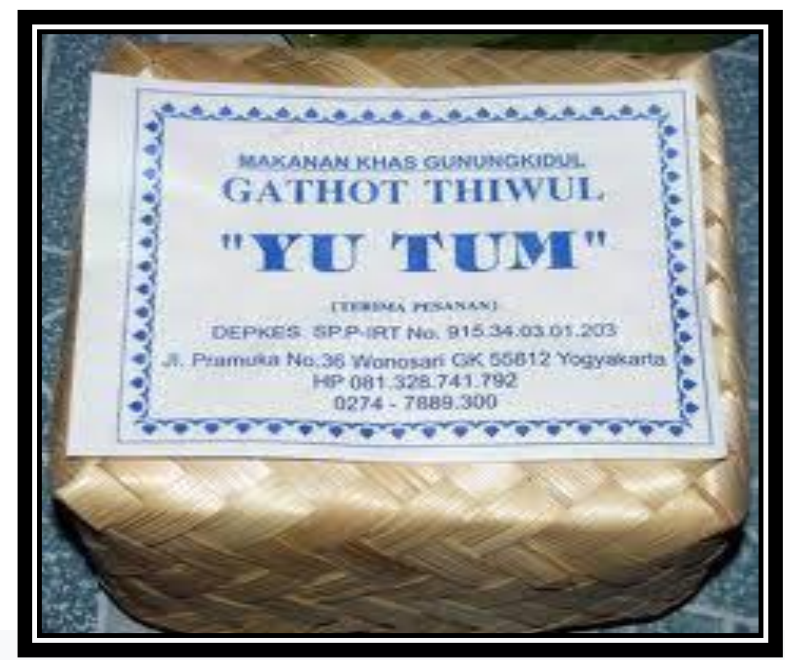

Picture 3 Tiwul 
Sekolah Pascasarjana Universitas Gadjah Mada. Yogyakarta

Factors that influence tourists' decisions to consume local

[5] Buchari. 2000. Manajemen Pemasaran dan Pemasaran Jasa. Alfabeta, Bandung

[6] Damardjati. 2007. Istilah-Istilah Dunia Pariwisata. Jakarta: Pradya Paramita

[7] DISPARTA. 2007a. Brosur: Pesona Di Ujung Tenggara Gunungkidul. Wonosari: Dinas Pariwisata dan Kebudayaan Gunung Kidul.

[8] DISPARTA. 2007b. Buku: Data Potensi Kepariwisatan Dan Kebudayaan Kabupaten Gunung Kidul. Wonosari. Dinas Pariwisata dan Kebudayaan Gunung Kidul.

\section{REFERENCES}

[1] Alma, B. 2004. Manajemen Pemasaran dan Pemasaran Jasa. Alfabeta,Bandung.

[2] Ariani, R.P. 1994. Studi Kelayakan Seni Kuliner Bali Mengenai Hidangan Tradisional Propinsi Bali. Laporan Penelitian. Singaraja: STKIP.

[3] Arikunto, S. 2002. Prosedur Penelitian Suatu Pendekatan Praktek. Edisi revisi VI. Rineka Cipta, Jakarta.

[4] Baiquni, M. 2004. Buku Ajar Manajemen Strategis. Program Studi Kajian Pariwisata

[13] Kotler, P. 2002. Manajemen Pemasaran, Edisi keduabelas. PT Macanan Jaya Cemerlang.

[14] Kotler, P. 2005. Manajemen Pemasaran. PT. Indeks Kelompok Gramedia, Jakarta.

[15] Marpaung. 2002. Pengetahuan Kepariwisataan. Bandung: Afabeta.

[16] Marsum, W.A. 2001. Restoran \& Segala Permasalahannya. Yogyakarta: Penerbit Andi.

[17] Moleong, L J. 2007. Metodologi Penelitian Kualitatif. Penerbit PT Remaja Rosdakarya Offset, Bandung

[18] Mulyana. R. 2002. Metode Penelitian Kualitatif. Bandung. PT. Remaja Rosda Karya

[19] Musanef. 1996. Manajemen Usaha Pariwisata di Indonesia. Jakarta: PT Agung.

[20] Nasution. 2006. Teknik Pengambilan Data dengan Metode Kualitatif. Jakarta : Grasindo

21] Pendit, S. N. 2002. Ilmu Pariwisata. Jakarta: Pradya Paramita.

[22] Rangkuti, F, 2006. Analisis SWOT, Tehnik Membedah Kasus Bisnis- Reorientasi Konsep Perencanaan Strategis Untuk Menghadapi Abad 21. Cetakan ke 14. Gramedia Pustaka Utama. Jakarta.

[23] Reid, dan Bojanic. 2006. Marketing for Hospitality and Tourism. Second Edition. Prentice Hall International, Inc.

[24] Sugiono, 2011. Metode Penelitian Kombinasi (Mixed Method), Bandung:Alfabeta
DISPARTA. 2007c. Leafleat: Mutiara Wisata dan Budaya. Wonosari: Dinas Pariwisata dan Kebudayaan Gunung Kidul.

[10] DISPARTA. 2007d. Leafleat: Welcome to Gunungkidul. Wonosari: Dinas, Pariwisata dan Kebudayaan Gunung Kidul.

[11] Echols, John M. \& Shadily, Hasan. 1993. Kamus Inggris Indonesia. Penerbit PT. Gramedia. Jakarta.

[12] Hsu, C. H. C dan Powers, T. 2002. Marketing Hospitality, Third Edition. New York: John Wiley \& Sons, Inc.

[25] Suriani, N. M. 2009. Seni Kuliner Bali Sebagai Salah Satu Daya Tarik Wisata Studi Kasus Di Warung Babi Guling Ibu Oka Di Kelurahan Ubud, Gianyar, Bali. Program Studi Magister (S2) Kajian Pariwisata. (Tesis). Denpasar: Universitas Udayana.

[26] Suwantoro, G. 1997. Dasar-Dasar Pariwisata.Yogyakarta: Andi.

[27] Swastha, B dan Irawan. 1996. Manajemen Pemasaran Modern. Edisi Keempat, Penerbit Liberty. Yogyakarta.

[28] Undang-Undang Republik Indonesia Nomor 10 Tahun 2009 Tentang Kepariwisataan.

[29] Winardi. 1992. Strategi Pemasaran. Cetakan ketiga. Penerbit Mandar Maju. Bandung.

[30] Yoeti, O.A.H. 2006. Pariwisata udaya dan Solusinya. Jakarta:Pradnya Paramitha

[31] http://www.gunungkidulkab.com (diakses 15 November 2014)

[32] http://www.dinaspariwisatakabgunungkidul.com (diakses 20 November 2014) 